MYTHA ND POETICS

A series edited by

GREGORY NAGY

\title{
Knowing Words:
}

Wisdom and Cunning in the Classical Traditions of China and Greece by Lisa Raphals

Also in the series

The Ravenous Hyenas and the Wounded Sun:

Myth and Ritual in Ancient India

by Stephanie W. Jamison

Poetry and Prophecy:

The Beginnings of a Literary Tradition

edited by James Kugel

The Traffic in Praise:

Pindar and the Poetics of Social Economy

by Leslie Kurke

Epic Singers and Oral Tradition

by Albert Bates Lord

The Language of Heroes:

Speech and Performance in the Iliad

by Richard P. Martin

Heroic Sagas and Ballads

by Stephen A. Mitchell

Greek Mythology and Poetics

by Gregory Nagy

Myth and the Polis

edited by Dora C. Pozzi and John M. Wickersham

Homer and the Sacred City

by Stephen Scully 



\section{KNOW ING WORDS}

Wisdom and Cunning in the Classical Traditions of China and Greece

\section{Lisa Raphals}

CORNELL UNIVERSITY PRESS

ITHACA AND LONDON 


\section{Copyright (C) 1992 by Cornell University}

All rights reserved. Except for brief quotations in a review, this book, or parts thereof, must not be reproduced in any form without permission in writing from the publisher. For information, address Cornell University Press, I 24 Roberts Place, Ithaca, New York 14850.

First published 1992 by Cornell University Press.

International Standard Book Number 0-80I4-26I9-7

Library of Congress Catalog Card Number 9I-55554

Printed in the United States of America

Librarians: Library of Congress cataloging information appears on the last page of the book.

(2) The paper in this book meets the minimum requirements of the American National Standard for Information Sciences-

Permanence of Paper for Printed Library Materials, ANSI Z39.48-1984. 
To Victor Raphals

1911-1982 
